\title{
Curso sobre Fabricação de Pilhas a Combustível de Óxido Sólido
}

Durante a realização do $\mathbf{3}^{\circ}$ Terceiro Seminário da Rede PaCOS (Rede Cooperativa Pilha Combustível de Óxido Sólido), pertencente ao Ministério da Ciência e Tecnologia, o Dr. Hans-Peter Buchkremer (à direita e com um círculo azul na foto), do Instituto para Materiais e Processos em Sistemas de Energia, no Forschungszentrum Jülich BmbH, Alemanha, ministrou um excelente curso sobre fabricação de pilhas a combustível de óxido sólido.

Nesta oportunidade foram abordados em detalhe todos os procedimentos para a fabricação de pilhas a combustível de óxido sólido, que são dispositivos eletroquímicos, que convertem a energia química contida em um combustível (hidrogênio, hidrocarbonetos, álcoois) em energia elétrica, com altíssima eficiência. Estes serão os principais conversores de energia do futuro e encontram-se atualmente em fase laboratorial e pré-comercial de desenvolvimento, em diferentes países do mundo. O laboratório onde o Dr. Buchkremer trabalha é o que está mais avançado no desenvolvimento de pilhas a combustível de óxido sólido na Europa.

Uma das principais conclusões do curso do Dr. Buchkremer foi que a grande barreira à convergência da tecnologia de pilhas a combustível de óxido sólido para aplicações comerciais está no desenvolvimento de materiais adequados ao desempenho requerido do dispositivo. Os conjugados eletrólitoeletrodos destas pilhas a combustível são constituídos de materiais cerâmicos que devem possuir propriedades difíceis de serem atingidas e mantidas na temperatura elevada em que são operados. Isso serviu de demonstração do papel relevante representado pelos desenvolvimentos de novos materiais, tema este largamente explorado na Revista Matéria.

Caso você realize desenvolvimentos de materiais de interesse para as pilhas a combustível de óxido sólido, não hesite em submetê-los para publicação na Revista Matéria.

Cordialmente,

Paulo Emílio V. de Miranda

Editor-Chefe da Revista Matéria

pmiranda@labh2.coppe.ufrj.br

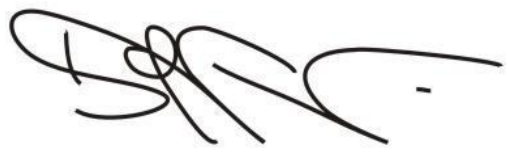

